\title{
RANCANG BANGUN KWH METER MENGGUNAKAN MIKROKONTROLER ATMEGA 8535
}

\author{
Arlenny $^{1}$, Elvira Zondra ${ }^{2}$ \\ 1,2 Program Studi Teknik Elektro, Fakultas Teknik, Universitas Lancang Kuning \\ Jl. Yos Sudarso km. 8 Rumbai, Pekanbaru, Telp. (0761) 52324 \\ Email: arlenny@unilak.ac.id, elviraz@unilak.ac.id
}

\begin{abstract}
ABSTRAK
Sistem KWH meter manual belum optimal dalam pencatatan energi listrik dan mengkontrol pemakaian energi listrik. Perancangan alat $\mathrm{kWh}$ digital sebagai penghitung dan kontrol beban pemakaian listrik menggunakan mikrokontroler AT Mega 8535, merupakan sebuah solusi alternatif sebagai antisipasi kelebihan pemakaian beban dan kemungkinan curang pihak pencatat meteran listrik tanpa harus mengganti kWh meter manual ke system token. Pada rancang bangun alat penghitung dan kontrol energi listrik yang terpakai ini, digunakan KWH meter manual yang dimodifikasi dengan menempatkan sensor optocoupler sebagai indikator pencacah angka daya telah terpakai pada cakram. Mikrokontroler AT Mega 8535 digunakan sebagai kendali dan pembatas daya terpakai. Sistem alat ukur dan kontrol yang didesain melakukan pengukuran besarnya daya listrik yang dipakai oleh beban dan dapat digunakan sebagai alternatif pembagi arus untuk tercapainya efisiensi pemakaian energi listrik. Alat ini bermanfaat untuk mengetahui nilai energi listrik yang terpakai dan dapat membatasi pemakaian daya listrik dengan kendali pada mikrokontroler. Pemakaian energi listrik yang terkontrol dan efisien dapat menghemat biaya pengeluaran pembayaran energi listrik.
\end{abstract}

Kata Kunci: Daya listrik, KWH meter, Mikrokontroller, Atmega 8535, Sensor optocoupler

\section{ABSTRACT}

The manual KWH meter system and the token system are likely not optimal in the recording of electrical energy and it may not able to control the used of electrical energy for practically consumptions. This research aims to design and develop reader equipment as well as control the load limitation of electric power using AT Mega 8535 microcontroller. In the design of reading and controlling electrical energy consumptions, the modified KWH meter was used by placing the auto-coupler sensor as the enumerator indicator the electric power consumption on the disc. AT Mega 8535 microcontroller was used to control and limitation of the electric power consumption. In this research, the measuring and control system was designed to record the amount of electrical power load used and it can be used as an alternative to the current divider for the achievement of the efficiency of practical electrical energy consumption. This equipment is useful to know the value of practical electrical energy consumption and can limit the use of electrical power with control on the microcontroller. The use of controlled and efficient electrical energy consumptions can save the cost of electricity energy expenditure.

Keywords: Electric power, KWH meter, Microcontroller, Atmega 8535, Sensor auto-coupler

\section{PENDAHULUAN}

KWH meter merupakan salah satu alat ukur yang banyak dipakai baik dilingkungan perumahan, perkantoran maupun industri. Fungsi utama KWH meter adalah untuk menghitung pemakaian energi listrik. Sistem KWH meter manual, jumlah pemakaian energi listrik akan dicatat secara manual oleh petugas PLN tanpa diketahui oleh pengguna listrik, nilai energi listrik yang telah terpakai. Pembacaan KWH meter manual dapat menimbulkan masalah bagi konsumen dan PLN jika petugas pembacaan meter secara tidak sengaja mengurangi atau menambah tagihan pelanggan. Saat ini masyarakat Indonesia masih percaya menggunakan meteran manual lebih hemat dibanding menggunakan meteran digital token keluaran PT PLN.
Pada penelitian ini rancang-bagun $\mathrm{kWh}$ Digital menggunakan Mikrokontroller ATMEGA 8535 merupakan salah satu solusi sebagai pencatat energi listrik yang diposisikan setelah $\mathrm{kWh}$ meter milik PT PLN. Sistem ini akan membantu pelanggan untuk membaca jumlah energy terpakai dan membatasi konsumsi energy listrik tanpa harus mengganti $\mathrm{kWh}$ meter manual menjadi $\mathrm{kWh}$ meter digital milik PLN. Selain itu sebagai pembanding hasil pencatatan listrik petugas dengan hasil yang tertera saat $\mathrm{kWh}$ meter digital milik pelanggan sehingga dapat mengurangi kesalahpahaman informasi tagihan.

Untuk mengkontrol penggunaan energi pada perangkat listrik, mikrokontroler menjadi salah satu pilihan bagi masyarakat pengguna energi listrik [2]. Mikrokontroler adalah rangkaian komponen elektronika terdiri dari mikroprosesor, RAM, ROM, timer, komponen 
I/O paralel dan serial, dan interrupt controller [3]. Sistem pengukuran dan kontrol pemakaian energi listrik menggunakan mikrokontroler sangat bermanfaat sebagai pengolah besaran arus listrik dan pemakaian daya yang terpakai sehingga dapat menjadi solusi alternatifpencatatan energi terpakai. Pengembangan $\mathrm{kWh}$ meter digital menggunakan mikrokontroler ini dapat menjadi acuan dalam rangka efisiensi energy rumah tangga dalam mengatur pemakaian energy dan besar biaya beban listrik pada ruangan yang dipasang setelah $\mathrm{kWh}$ meter manual milik PLN.

Penelitian ini bertujuan merancang dan membuat alat penghitung serta kontrol/pembatas beban dan daya listrik menggunakan mikrokontroler AT Mega 8535 dengan menempatkan sensor optocoupler sebagai indikator pencacah angka daya telah terpakai.

\section{METODE PENELITIAN}

Desain dan pembuatan alat ukur dan kontrol $\mathrm{KWH}$ meter digital yang dibuat terdiri dari beberapa komponen alat yaitu KWH meter, sensor optocoupler, relay dan mikrokontroler Atmega 8535. Desain alat menggunakan KWH meter manual yang dimodifikasi dengan menempatkan sensor optocoupler sebagai indikator pencacah angka daya telah terpakai pada cakram. Untuk mengkontrol dan sebagai pembatas daya terpakai digunakan mikrokontroler Atmega 8535. Sistem alat ukur dan kontrol yang didesain melakukan pengukuran besarnya daya listrik yang dipakai oleh beban dan dapat digunakan sebagai alternatif pembagi arus untuk tercapainya efisiensi pemakaian energi listrik.

\section{kWh Meter Analog}

KWHmeter analog (Gambar 1) bekerja meggunakan metode induksi medan magnet, dimana medan magnet tersebut menggerakkan piringan yang terbuat dari aluminium [1]. Bagian utama dari sebuah $\mathrm{KWH}$ meter analog adalah kumparan tegangan, kumparan arus, piringan aluminium, magnet tetap yang tugasnya menetralkan piringan aluminium dari induksi medan magnet dan gear mekanik yang mencatat jumlah perputaran piringan aluminium.

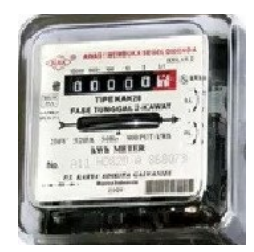

Gambar 1. KWH meter analog

\section{Mikrokontroler Atmega 8535}

Mikrokontroler ialah suatu chip (rangkaian terintegrasi yang sangat komplek) yang memproses data dari input yang diterima pada suatu sistem digital.
Mikrokontroler digunakan untuk orientasi pengontrolan, seperti pengontrolan temperatur, penampilan display LCD, pemprosesan sinyal digital dan sebagainya [4].

Mikrokontroler berbeda dengan komputer, yang mampu menangani berbagai macam program aplikasi seperti pengolahan kata, angka dan lain-lain. Mikrokontroler hanya mampu untuk satu aplikasi tertentu saja. Perbedaan lainnya terletak pada perbandinagn RAM dan ROM. Pada sistem komputer perbandingan RAM dan ROM sangat besar, artinya program-program pengguna disimpan dalam ruang RAM sebagai tempat penyimpanan sementara. Sedangkan antarmuka perangkat keras atau program kontrol disimpan dalam ROM yang ukurannya lebih besar.

Secara umum, arsitektur mikrokontroler Atmega 8535 terdiri dari [7]:

- 32 saluran I/O (Port A, Port B, Port C dan Port D)

- 10 Bit 8 channel ADC (Analog Digital Converter) 4 channel PWM, 6 sleep modes: Idle, ADC noise reduction, power save, power down, stand-by dan extended stand by.

- Analog komparator

- Watchdog timer dengan osilator internal

- 512 byte SRAM

- 512 byte EEPROM

- $8 \mathrm{~kb}$ flash memori dengan unit interupsi internal dan external

- Port antarmuka SPI 8535 memori map

- Port USART untuk komunikasi serial dengan kecepatan 2,5 MBPS 4,5 V sampai 5,5 V operation, 0 sampai 16 MHZ.
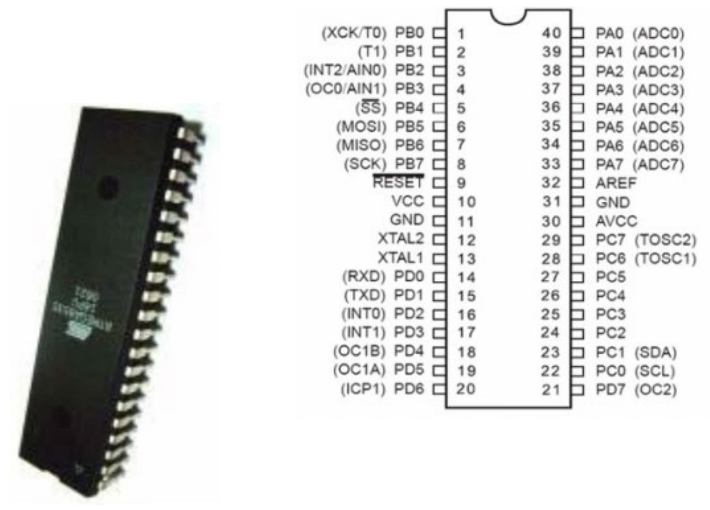

Gambar 2. Mikrokontroler Atmega8535 dan konfigurasi [7]

Penelitian ini menggunakan mikrokontroler AVR dari Atmega 8535 karena mikrokontroler ini memiliki fasilitas lengkap, proses instruksi cepat dan didukung oleh perangkat lunak Evaluasi Vision AVR untuk simulasi dan kompiling. Selain itu, mikrokontroler ini memiliki fitur khusus untuk mengkonversi sinyal analog ke sinyal digital, karena output sensor adalah sinyal analog, sementara sinyal ini perlu diproses sebagai sinyal digital di mikrokontroler. Selanjutnya, bahasa $\mathrm{C}$ digunakan untuk pemrograman mikrokontroler Atmega 8535. Code Vision AVR adalah 
salah satunya kompiler perangkat lunak berdasarkan bahasa C untuk AVR aplikasi terintegrasi oleh ANSI dalam sistemnya. Code Vision AVR menyediakan code generator atau code wizard $A V R$ yang memberikan fasilitas untuk mengembangkan suatu program yang diinginkan.

\section{Sistem Kontrol}

Sistem kontrol memiliki arti mengatur atau meng arahkan dan memerintah dimana untuk pelaksanaan tugas tersebut dibutuhkan susunan komponen fisik yang terhubung sedemikian rupa sesuai fungsinya. Pada kendali system yang dimaksud dengan sistem masukan adalah rangsangan yang ditetapkan pada sebuah pengendali dari sumber energi luar sehingga menghasilkan tanggapan. Sedangkan keluaran merupakan tanggapan yang sebenarnya yang didapat pada sistem pengendali. Tanggapan ini bisa sama atau tidak dengan tanggapan yang terdapat pada masukan.

\section{Sistem Loop Terbuka}

Diagram kerja sistem loop terbuka dapat dilihat pada gambar 3 berikut :

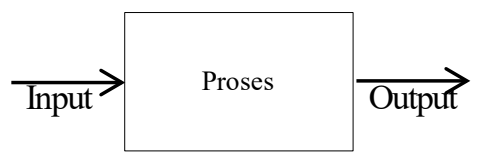

Gambar 3. Sistem loop terbuka

Pada loop terbuka output tidak memiliki efek terhadap proses pengendalian, artinya pada loop terbuka output tidak sebagai pembanding hasil input. Dengan kata lain hasil output sudah diketahui dan tidak memiliki gangguan internal maupun eksternal.

\section{Loop Tertutup} berikut.

Diagram Loop tertutup dapat dilihat pada gambar 4

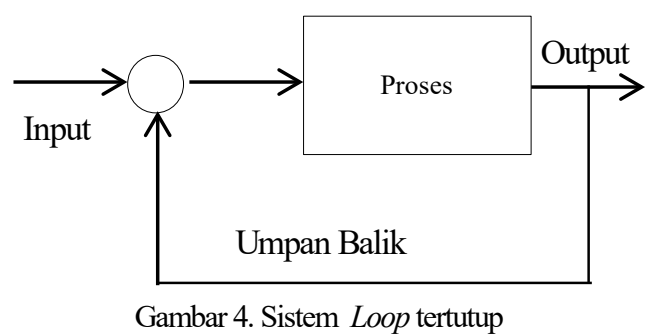

Sistem loop tertutup adalah sistem yang menjaga kondisi antara sinyal input dan output seimbang menggunakan perbedaan keduanya (sinyal gangguan), sebagai media pengendali. Dibandingkan dengan sistem kontrol loop terbuka, sistem kontrol loop tertutup memang lebih rumit, mahal, dan sulit dalam desain. Akan tetapi tingkat kestabilannya yang relatif konstan dan tingkat kesalahannya yang kecil bila terdapat gangguan dari luar, membuat sistem kontrol ini lebih banyak menjadi pilihan para perancang sistem kontrol.

\section{Proses Perancangan kWh Digital}

Tahapan dalam perancangan $\mathrm{kWh}$ digital menggunakan Mikrokontroler ATMEGA 8535 dapat dilihat pada gambar 5 berikut :

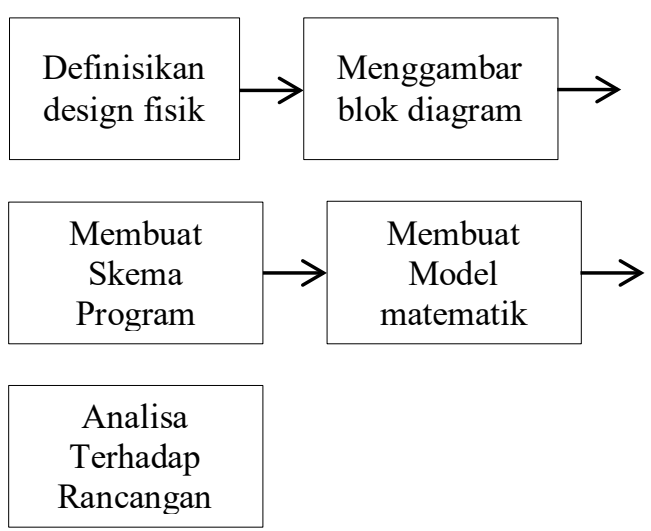

Gambar 5. Proses Tahapan Perancangan

Pada perancangan sistem kontrol, utama yang harus dipersiapkan adalah menganalisa sistem yang akan dikontrol terlebih dahulu. Pembuatan model yang lebih sederhana dapat mempermudah dalam menganalisa sistem tersebut. Kemudian pemodelan tersebut dapat diumpamakan dalam suatu persamaan matematis, sehingga aplikasi perhitungan matematis akan sangat memungkinkan dalam menganalisa sistem tersebut.

Persoalan lain yang seringkali timbul dalam perancangan sistem kontrol adalah masalah kestabilan. Suatu sistem yang stabil akan memberikan kinerja yang lebih baik daripada sistem yang tidak stabil bila diberikan gangguan dari luar.

\section{Kestabilan Sistem}

Sebuah sistem dikatakan tidak stabil jika tanggapannya terhadap suatu masukan menghasilkan osilasi yang keras atau bergetar pada suatu amplitudo/harga tertentu. Sebaliknya suatu sistem disebut stabil jika sistem tersebut akan tetap dalam keadaan diam atau berhenti kecuali jika dirangsang (dieksitasi oleh suatu fungsi masukan dan akan kembali dalam keadaan diam jika eksitasi tersebut dihilangkan). Ketidakstabilan merupakan suatu keadaan yang tidak menguntungkan bagi suatu sistem lingkar tertutup sedangkan pada suatu sistem lingkar terbuka tidak dapat tidak harus stabil. Jelas untuk memperoleh nilai yang memberikan manfaat, praktis sebuah sistem kendali harus stabil. Masukan sistem tidak memberikan pengaruh terhadap kestabilan suatu sistem sehingga jika sistem tersebut stabil terhadap suatu masukan maka sistem akan stabil juga untuk masukan lain. Kestabilan hanya bergantung pada karakteristik sistem itu sendiri. 


\section{Relay}

Relay adalah saklar yang menggunakan prinsip elektromagnetik untuk menggerakkan kontak saklar sehingga arus listrik tegangan rendah dapat menghantarkan listrik yang bertegangan lebih tinggi. Relay terdiri dari dua bagian utama: elektromagnet (coil) dan mekanikal (kontak saklar). Kontak poin relay terdiri: Normally Close (NC) yaitu kondisi awal sebelum diaktifkan akan selalu berada di posisi CLOSE (tertutup) dan Normally Open (NO) yaitu kondisi awal sebelum diaktifkan akan selalu berada di posisi OPEN (terbuka). Relay yang digunakan optoisolated 2 channel 5 V DC keluaran 250 VAC $10 \mathrm{~A}$,

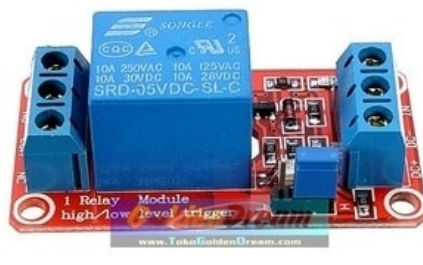

Gambar 6. Relai Optoisolated

\section{Sensor Optocoupler}

Sensor optocoupler merupakan alat untuk mendeteksi perubahan sinar inframerah pemicu on-off yang dipakai untuk mendeteksi jarak ataupun pergerakan suatu benda. Bagian dari sensor optocoupler: sebuah LED inframerah sebagai transmitter dan sebuah fototransistor sebagai receiver. Jadi sensor optocoupler adalah komponen elektronik yang bekerja berdasarkan picu cahaya optik, yang terdiri dari transmitter LED infra merah dan receiver (phototransistor) spektrum infra merah yang merupakan sumber cahaya menghasilkan energy panas yang lebih besar dari cahaya tampak.

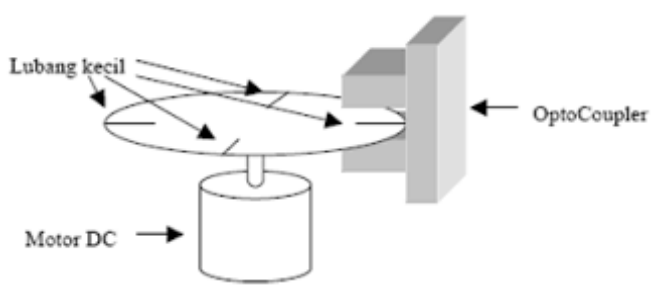

Gambar 7. Posisi Kerja Sensor Optocoupler

Optocoupler juga dapat dikatakan sebagai gabungan dari LED infra merah dengan fototransistor yang terbungkus menjadi satu chips. Cahaya infra merah termasuk dalam gelombang elektromagnetik yang tidak tampak oleh mata telanjang. Sinar ini tidak tampak oleh mata karena mempunyai panjang gelombang , berkas cahaya yang terlalu panjang bagi tanggapan mata manusia. Sinar infra merah mempunyai daerah frekuensi 1 x $1012 \mathrm{~Hz}$ sampai dengan 1 x $1014 \mathrm{GHz}$ atau daerah frekuensi dengan panjang gelombang $1 \mu \mathrm{m}-1 \mathrm{~mm}$.
Prinsip kerja dari optocoupler adalah :

a. Jika antara Photodiode dan LED terhalang maka Photodiode tersebut akan off sehingga output dari kolektor akan berlogika high.

b. Sebaliknya jika antara Photodiode dan LED tidak terhalang maka Photodiode dan LED tidak terhalang maka Photodiode tersebut akan on sehingga outputnya akan berlogika low.

Sebagai piranti elektronika yang berfungsi sebagai pemisah antara rangkaian power dengan rangkaian kontrol. Komponen ini merupakan salah satu jenis komponen yang memanfaatkan sinar sebagai pemicu on/off-nya. Opto berarti optic dan coupler berarti pemicu. Sehingga bisa diartikan bahwa optocoupler merupakan suatu komponen yang bekerja berdasarkan picu cahaya optic opto-coupler termasuk dalam sensor, dimana terdiri dari dua bagian yaitu transmitter dan receiver.

\section{Seven Segmen}

Seven Segmen adalah penampil angka dengan lampu LED yang berjumlah 8 (delapan) buah. dengan susunan a sampai h yang mana salah satu terminal terhubung kaki common. Pada Rangkaian Digital $\mathrm{kWh}$ meter seven segmen berfungsi sebagai pembaca putaran piringan cakram $\mathrm{kWh}$ meter. Berikut tampilan seven sement

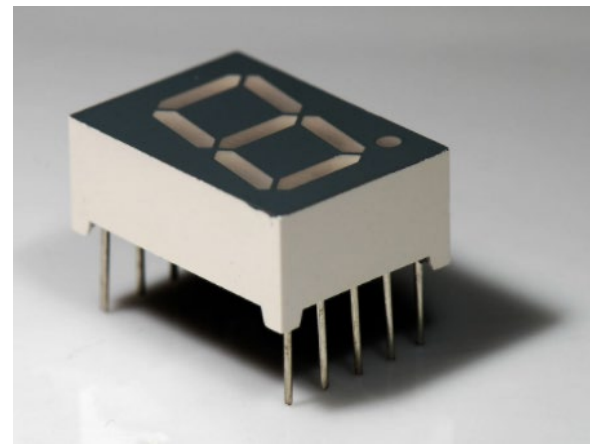

Gambar 8. Tampilan Seven Segment

Seven segment terdiri dari 2 konfigurasi, yaitu common anoda dan common katoda. Pada seven segment tipe common anoda, anoda dari setiap LED dihubungkan menjadi satu kemudian dihubungkan ke sumber tegangan positip dan katoda dari masingmasing LED berfungsi sebagai input dari seven segment, seperti ditunjukkan pada gambar 9 berikut ini 


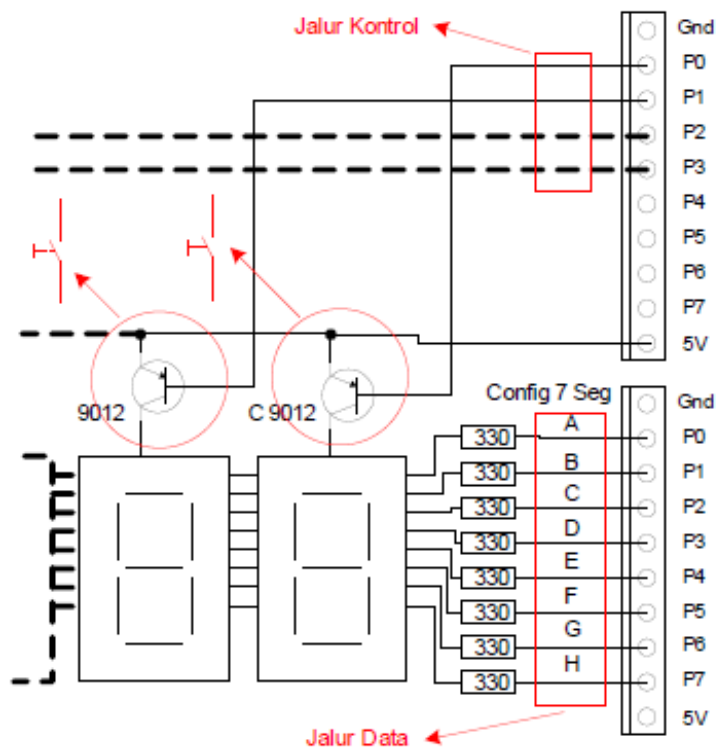

Gambar 9. Jalur data dan jalur kontrol Multi seven segmen

Sesuai dengan gambar di atas, maka untuk menyalakan salah satu segmen, maka katodanya harus diberi tegangan 0 volt atau logika low. Misalnya jika segmen a akan dinyalakan, maka katoda pada segmen a harus diberi tegangan 0 volt atau logika low, dengan demikian maka segmen a akan menyala. Demikian juga untuk segmen lainnya.

\section{Struktur Bahasa CodeVision AVR}

Pemakaian mikrokontroler banyak diaplikasikan pada berbagai alat rumah tangga, otomotif, sampai dengan kendali, Saat ini penggunaan mikrokontroler telah digunakan pada dunia pendidikan. Salah satu varian yang banyak dipelajari dan digunakan adalah produk dari ATMEL dengan type keluarga AVR. Banyak software yang dapat digunakan untuk memprogram mikrokontroler keluarga AVR, dengan bahasa pemrograman masingmasing.

Perkembangan bahasa pemrograman yang dimulai dari bahasa tingkat rendah (bahasa assembly/bahasa mesin) sampai dengan bahasa tingkat tinggi (salah satunya bahasa C). Bagi mikrokontroler bahasa assembly merupakan bahasa yang mudah untuk diterjemahkan bagi prosesornya, sehingga dikatakan sebagai bahasa tingkat rendah. Sedangkan bahasa tinggkat tinggi merupakan bahasa yang sulit diterjemahkan oleh prosesor yang ada di didalam mikrokontroler. Pemilihan bahasa $\mathrm{C}$ sebagai bahasa pemrograman untuk mikrokontroler dikarenakan mudah dipahami dan diterjemahkan bagi user atau programmer.

Bahasa C memiliki struktur pemrograman yang khusus, selain itu bahasa $\mathrm{C}$ memiliki sifat case sensitive. Artinya tersebut adalah bahwa penulisan kata/word program sangat sensitif dengan mendeteksi perbedaan kapital tidaknya huruf yang digunakan. Satu huruf yang berbeda pada satu kata yang diulang, menyebabkan software tidak akan bisa meng-compile seluruh program yang dibuat.
Setiap bahasa pemrograman memiliki type data masing-masing. Type data merupakan jangkauan suatu data yang mampu/dapat dikerjakan/diolah oleh mikroprosesor dalam program yang dibuat. Penggunaan type data ini juga harus sesuai kebutuhan dan disesuaikan dengan fungsi setiap data. Pemilihan penggunaan type data dapat mempengaruhi besarnya memory file yang dibuat.

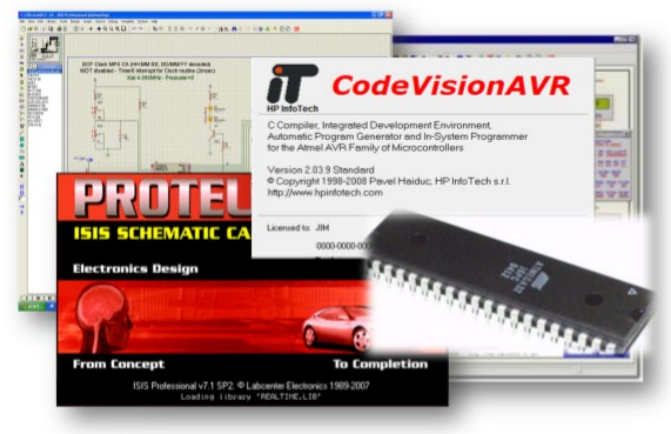

Gambar 10. Tampilan Pogram Bahasa CodeVision AVR

Sejauh yang diijinkan oleh arsitektur dari AVR, dengan tambahan beberapa fitur untuk mengambil kelebihan khusus dari arsitektur AVR dan kebutuhan pada sistem embedded. CodeVisionAVR juga mempunyai Automatic Program Generator bernama CodeWizardAVR, yang mengizinkan Anda untuk menulis, dalam hitungan menit, semua instruksi yang diperlukan untuk membuat beberapa fungsi-fungsi tertentu. Dengan fasilitas ini mempermudah para programmer pemula untuk belajar pemrograman mikrokontroler menggunakan CodeVisionAVR. Secara garis besar bagian-bagian CodeVisionAVR dapat diuraikan seperti gambar berikut ini :

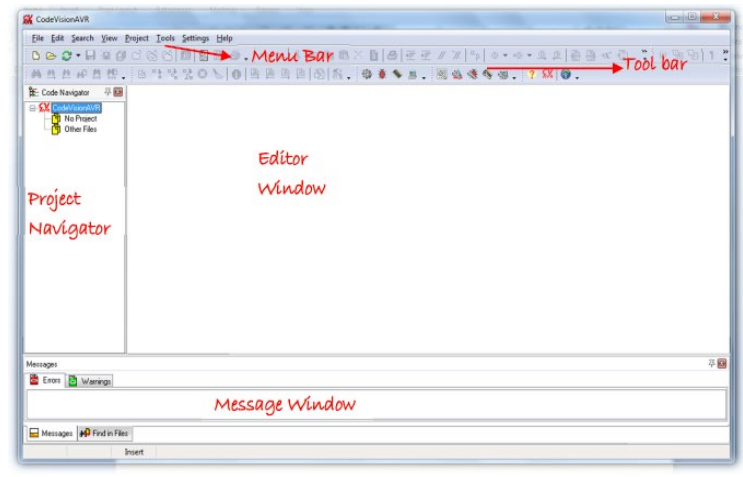

Gambar 11. Tampilan window utama CodeVisionAVR

\section{HASIL DAN PEMBAHASAN}

Rancang bangun $\mathrm{kWh}$ meter digital menggunakan mikrokontroler ATMEGA 8535, dengan menggunakan bahasa pemograman CodeVisionAVR dengan struktur penyusunan bahasa pemograman sebagai berikut : 


\section{Kepala Program}

Struktur bahasa kepala program pada rancang bangun $\mathrm{kWh}$ meter digital menggunakan mikrokontroler 8535 adalah sebagai berikut. :

\#include $<$ mega8535.h $>$

\#include $<$ delay.h $>$

unsigned char

angka[10] $=\{0 \mathrm{~b} 11000000,0 \mathrm{~b} 11111001,0 \mathrm{~b} 10100100$, 0b10110000,0b10011001,0b10010010,0b10000010, Ob11111000,0b10000000,0b10010000\};

int

satuan,puluhan,ratusan,ribuan,data,data_temp, $\mathrm{x}, \mathrm{y}$;

Pada kepala program rancang bangun $\mathrm{kWh}$ meter digital menggunakan mikrokontroler ATMEGA 8535, angka hitung maksimal dibatasi hingga 10 kali putaran piringan cakram kWh meter. Angka 10 kali putaran tersebut dapat diubah sesuai kebutuhan jumlah energi yang akan digunakan.

\section{Sistem Kontrol kWh Digital ATMEGA 8535}

Sistem kontrol $\mathrm{kWh}$ Digital menggunakan Mikrokontroller ATMEGA 8535 menggunakan sistem loop tertutup sebagaimana gambar 12 berikut :

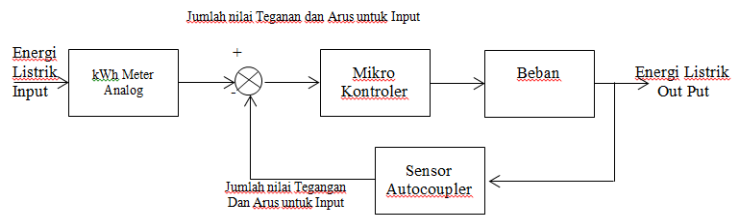

Gambar 12. Sistem Kontrol kWh Digital Mikrokontroler ATMEGA 8535

Pada Gambar 12 Energi listrik sebagai masukan yang diumpankan pada $\mathrm{kWh}$ meter analog memberikan nilai energi terpakai yang dihitung oleh piringan cakram. Selanjutnya Mikrokontroler ATMEGA 8535 mengendalikan pemakaian beban listrik sesuai yang ditentukan oleh nilai yang diumpankan pada sensor autocoupler, setelah batas pemakaian beban terpenuhi sesuai kuota yang diinformasikan melalui penampil digital seven segment, maka mikrokontroler secara automatis akan mengaktifkan fungsi relai sebagai pemutus energi listrik.

\section{Tubuh Program}

Tubuh program berisi perintah lanjutan dari kepala program Rancang bangun $\mathrm{kWh}$ meter digital menggunakan mikrokontroler ATMEGA 8535, adapun tubuh program sebagai berikut :

void ambil_data()

\{

data_temp $=$ data; satuan=data_temp $\% 10$;

puluhan $=($ data temp $/ 10) \% 10$;

ratusan $=($ data temp $/ 100) \% 10$;

ribuan $=($ data_temp $/ 1000) \% 10$;

\}

void tampilkan_seven_segment()

\{

PORTD. $0=1$;

PORTD. $1=0$;

PORTD. $2=0$;

PORTD. $3=0$;

PORTC $=$ angka[satuan $]$

delay ms(100);

PORTD. $0=0$;

PORTD. $1=1$;

PORTD. $2=0$;

PORTD. $3=0$;

PORTC $=$ angka[puluhan];

delay_ms(100);

PORTD. $0=0$;

PORTD. $1=0$;

PORTD. $2=1$;

PORTD. $3=0$;

PORTC $=$ angka[ratusan];

delay $\mathrm{ms}(100)$;

PORTD. $0=0$;

PORTD. $1=0$;

PORTD. $2=0$;

PORTD. $3=1$;

PORTC $=$ angka[ribuan $]$;

delay_ms(100);

\}

void main (void)

data $=0$;

PORTA $=0 \times 00$;

DDRA $=0 \mathrm{xFF}$;

PORTB $=0 \times \mathrm{xF}$;

$\mathrm{DDRB}=0 \times 00$;

PORTC $=0 \times 00$;

$\mathrm{DDRC}=0 \mathrm{xFF}$

PORTD $=0 \times F F$;

$\mathrm{DDRD}=0 \mathrm{xFF}$;

$\mathrm{y}=0$;

while (1)

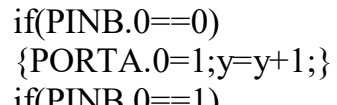




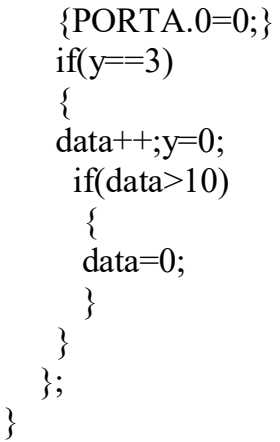

Pada bagian deklarasi, variabel program dibagi dua bagian utama yakni untuk pendeklarasian tampilan data hitung dan pendeklarasian data tampilan seven segment. Pada pendeklarasian data tampilan seven segment, pengambilan data diawali dengan angka satuan, angka puluhan, angka ratusan dan angka ribuan. Pada masingmasing tampilan data terdapat inisialisasi port. Inisialisasi PORT bertujuan untuk memerintahkan fungsi PORT yang dituju sebagai masukan/keluaran serta nilai gangguannya.

KWh meter digital bekerja berdasarkan input dari sensor optocoupler yang ditempel pada tutup piringan KWh meter. Sensor optocoupler akan memberi nilai output low saat infared sensor terhalang atau terputus, yang mana logika high dan low akan menjadi input bagi mikrokontroler sebagai pengendali utama untuk memberikan output yang diterima seven segment.

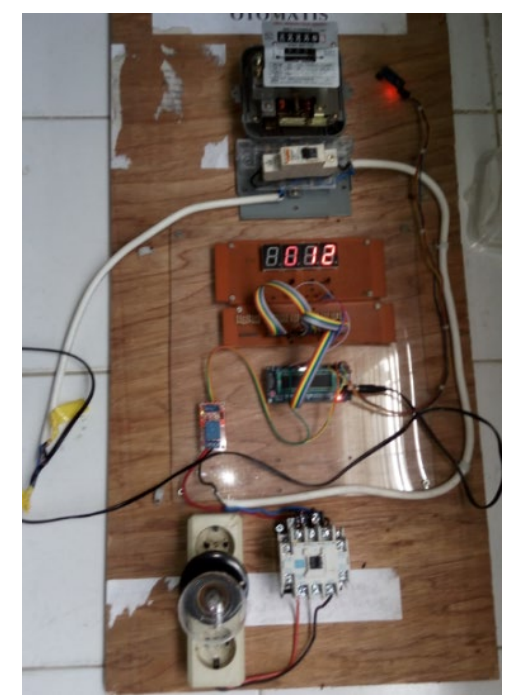

Gambar 13. Rancang Bangun Mikro Kontroler ATMEGA 8535

Pada bagian subrutin atau blok program yang akan mengerjakan perintah secara berulang oleh mikroprosesor selama mikrokontroler hidup, dimunculkan perintah penjumlahan angka pada setiap hitungan sensor optocoupler. Nilai hitungan akan bertambah 1 setiap sensor mendeteksi on. Setelah hitungan melebihi angka 10 maka program akan mengaktifkan kerja relai sebagai pemutus dan angka pada layar seven segment dikembalikan nilai menjadi 0. Gambar 13 adalah rancang bangun $\mathrm{kWh}$ meter digital menggunakan mikrokontroler ATMEGA 8535.

Penghitungan angka di tampilan seven segment pada rancang bangun alat $\mathrm{kWh}$ meter digital ini terdapat gangguan yang disebabkan oleh tidak terposisikannya dengan baik sensor optocoupler.

\section{KESIMPULAN}

\section{Kesimpulan}

Pada Rancang bangan kWh meter menggunakan Mikrokontroller ATmega 8535 didapatkan kesimpulan :

1. Penghitungan angka ditampilan seven segment pada rancang bangun alat $\mathrm{kWh}$ meter digital ini terdapat gangguan yang disebabkan oleh tidak terposisikannya dengan baik sensor optocoupler.

2. $\mathrm{kWh}$ meter digital beradasarkan input dari sensor optocoupler, sehingga posisi penempatan sinyal autocopler haruslah pada posisi yang kokoh

\section{Saran}

Untuk mendapatkan kondisi keandalan produk rancang bangun $\mathrm{kWh}$ meter digital ini diperlukan :

1. Pengukuran dan pengujian besaran nilai input terhadap output.

2. Pengujian terhadap keandalan terhadap pemakaian yang lama terhadap komponen, dan kestabilan nilai besaran input terhadap output.

\section{DAFTAR PUSTAKA}

[1] Fitriastuti, F. dan Siswadi, Aplikasi KWH (Kilo Watt Hour) Meter Berbasis Microntroller Atmega 32 untuk Memonitor Beban Listrik. Jurnal Kompetensi Teknik Vol. 2, No. 2, 2011.

[2] Shajahan, A.H. dan Anand A, Data Acquisition and Control Using Arduino-Android Platform: Smart Plug. IEEE International Conference on Energy Efficient Technologies for Sustainability (ICEETS), Pp 241-244, 10-12 April, 2013.

[3] Sharef, Z.T. Isa, M.A., Hasan, F.A., Toorani M.A. dan Yadgar R.A., Automated Meter Reading System Based on Basic Stamp2 Microcontroller, Asian Journal of Scientific Research, Vol. 6, No. 1, Pp. 88-97, 2013.

[4] Sulistiyo, A. Prasetio, D.A dan Supardi A., KWh Meter Digital Terkoneksi Personal Computer (PC) Berbasis Mikrokontroler Atmega16." (2012). 
[5] Loss, P.A.V., Lamego, M.M., Sousa, G.C.D. and Vieira, J.L.F., A Single Phase Microcontroller Based Energy Meter, Instrumentation and Measurement Technology Conference, 18-21 May 1998, in Conference Proceedings, IEEE. Vol. 2, 1998.

[6] Setiono, A., Prototipe Aplikasi KWh Meter Digital Menggunakan Mikrokontroler ATMEGA8535 untuk Ruang Lingkup Kamar, Jurnal Ilmu Pengetahuan dan Teknologi TELAAH, Vol. 26, Pp. 32-39, November 2009. 